\title{
Ultrasonographic Assessment of Early Bone Erosions in Addition to Soft-Tissue Changes in Rheumatoid Arthritis
}

\author{
Romatoid Artritte Yumuşak Doku Değişikliklerine ilaveten Erken Erozyonların \\ Ultrasonografik Değerlendirilmesi
}

Mustafa Turgut Yıldızgören, Kasım Osmanoğlu, Onur Velioğlu, Halil Öğüt

Mustafa Kemal University Faculty of Medicine, Department of Physical Medicine and Rehabilitation, Hatay, Turkey

\section{To the Editor;}

A 55-year old male presented to the outpatient clinic with painful swelling and morning stiffness in both wrists and finger joints which had started 6 weeks ago. The morning stiffness in both hands and wrists lasted for up to 2 hours and improved with activity. Detailed questioning revealed no significant past medical history. On physical examination, there was deformity and swelling on the wrists and hands. Soft-tender swellings were determined in the metacarpophalangeal (MCP) and proximal interphalangeal joints of the second through fifth digits of both hands. The serum C-reactive protein (CRP) level, anti-CRP level and erythrocyte sedimentation rates (ESR) were increased ( $C R P=68 \mathrm{mg} / \mathrm{L} ; E S R=87 \mathrm{~mm} / \mathrm{h}$; anti-CRP=364 UI/ $\mathrm{mL}$ ). Rheumatoid factor levels were within the normal ranges. The leukocyte count, hepatitis markers, anti-nuclear antibodies, anti-dsDNA were also normal. Antero-posterior hand and wrist radiographs showed soft tissue swelling without erosion (Figure 1a). Longitudinal (Figure 1b) and axial (Figure 1c) ultrasound (US) images showed effusion, and cortical bone erosion on the radial side of the $2^{\text {nd }} \mathrm{MCP}$ joint (arrow).

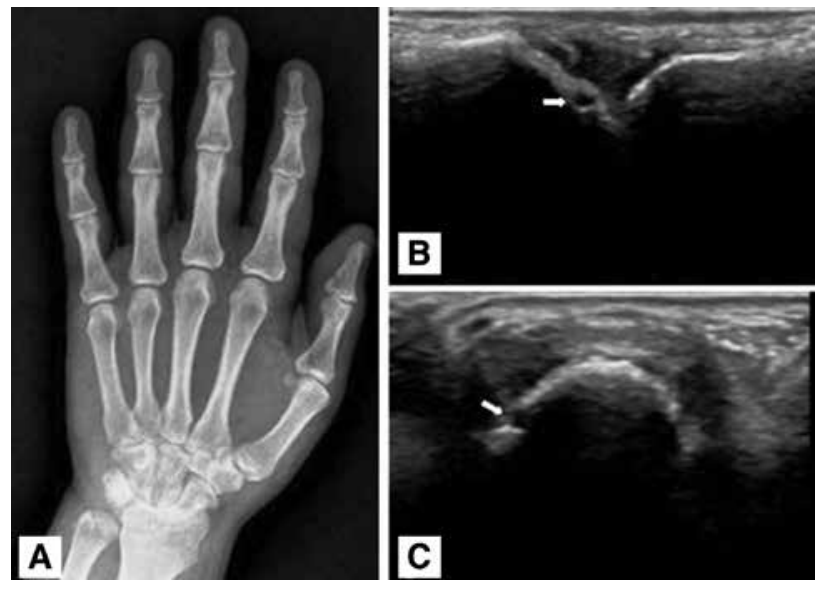

Figure 1. Anteroposterior hand\&wrist radiograph showing softtissue swelling without erosion (A), longitudinal (B) and axial, (C) ultrasound image cortical bone erosion on radial side of the $2^{\text {nd }}$ metacarpophalangeal joint (arrow)
Structural damage in rheumatoid arthritis begins at a very early stage of the disease. In daily clinical practice, although conventional radiography is the most common imaging tool adopted for detecting and scoring joint damage, it is not adequate to detect early bone erosions and soft-tissue changes (1). On the other hand, a number of reports have described the efficacy of magnetic resonance imaging (MRI) in demonstrating synovitis and bone changes with a greater sensitivity than conventional radiography (2). US, as a non-invasive technique, can detect sensitively small bone erosions (3). US might be considered as a valuable tool for early detection of bone erosion especially when MRI is not available or affordable. In addition, US seems to be more reliable when the disease is more active. US can be considered a reliable technique which detects more erosions than radiography, especially in early RA.

Keywords: Ultrasound, arthritis, early erosion

Anahtar kelimeler: Ultrason, artrit, erken erozyon

Ethics

Peer-review: Internal peer-reviewed.

\section{Authorship Contributions}

Concept: Mustafa Turgut Yıldızgören, Design: Mustafa Turgut Yıldızgören, Data Collection or Processing: Kasım Osmanoğlu, Onur Velioğlu, Analysis or Interpretation: Kasım Osmanoğlu, Onur Velioğlu, Literature Search: Halil Öğüt, Onur Velioğlu, Writing: Halil Öğüt.

Conflict of Interest: No conflict of interest was declared by the authors.

Financial Disclosure: The authors declared that this study has received no financial support.

\section{References}

1. Salaffi F, Gutierrez M, Carotti M. Ultrasound versus conventional radiography in the assessment of bone erosions in rheumatoid arthritis. Clin Exp Rheumatol 2014;32(1 Suppl 80):85-90.

2. Uetani M. Imaging approach for the evaluation of the bone and joint destruction in rheumatoid arthritis. Clin Calcium 2007;17:453-62.

3. Yildizgoren MT, Demirkapi M, Turhanoglu AD. Ultrasonography can be used to assess phalanx fractures. I Hand Surg Am 2015;40:1057-8.

Address for Correspondence/ Yazışma Adresi: Mustafa Turgut Yıldızgören MD, Mustafa Kemal University Faculty Medicine, Department of Physical Medicine and Rehabilitation, Hatay, Turkey hone: +90 3262291000 E-mail: ftr.mustafaturgut@hotmail.com Received/Geliş Tarihi: 06.09.2015 Accepted/Kabul Tarihi: 28.09.2015 